\title{
Agriculture: From a Development Perspective to Plant Resource Domestication
}

\author{
Benjamin E. Uchola \\ Agriculture and Agricultural Technology, Federal University, Dutsin-ma, Nigeria
}

Email address:

buchola@fudutsinma.edu.ng

To cite this article:

Benjamin E. Uchola. Agriculture: From a Development Perspective to Plant Resource Domestication. American Journal of Agriculture and Forestry. Vol. 3, No. 4, 2015, pp. 127-134. doi: 10.11648/j.ajaf.20150304.12

\begin{abstract}
Plant Resource Domestication (PRD) is generally accepted as a continuum of different phases of human-plant interactions but its value in the development of agriculture remains to be explored. The origin of PRD can be traced to an initial transfer of valuable native plants from their natural habitats to agricultural ecosystems. The later phase of the domestication process involves the genetic improvement of cultivated plants. Plants subjected to the different aspects of domestication manifest a modification to their form and an enhancement of their function. As cultivated plants manifest profound changes in morphology and physiology so also they progress into becoming crops that are highly productive. The higher productivity that defines the latter stages of PRD is often achieved through series of selection and plant breeding programmes. These stages or Plant Development Levels provide clues into the development pattern intrinsic to agriculture and inform the proposal concerning the nature of agriculture as well as its development.
\end{abstract}

Keywords: Human-Plant Interactions, Plant-Crop Relationship, Plant-Development-Levels, Plant Selection

\section{Introduction}

Plant Resource Domestication (PRD) is closely linked to the development of crop-based agriculture. It highlights the events leading up to the transfer of wild plants from their natural habitat to artificial environment [1-5]. Plant Resource Domestication (PRD) explains not only the origin of cultivated plants in agricultural ecosystems but also the development of the domestication syndrome [6-8]. It is also a key to understanding the different levels of transformation that accompanied native plants as they transit their wild state into becoming crops [9]. But most importantly, domestication of plants is generally credited with the emergence of varieties of cultivated plants that are either resistant to diseases, adapted to harsh climatic conditions, richer in essential nutrients, higher in productivity or combine a number of these attributes [10-14]. Conversely, as PRD engenders the development of crops and their cultivars, so does it facilitates the demise of the traditional practice of exploiting native plant resource.

A number of scientific studies on the different aspects of Plant Resource Domestication (PRD) abound. Some of such investigation place emphasis on certain aspects of domestication especially on the bio-geographical/ genetic origin of plants [15-18] , their evolutionary history [19]-[23] or the development of distinct domestication syndrome $[7,8,12,14,24]$. Others deal mainly with the genetic improvement of cultivated plant through the process of selection and hybridization [25-29]. A number of relatively recent studies attend to the use of beneficial genes from crop wild relatives in breeding programmes involving cultivated plants $[11,13,30]$. These investigations explore the different aspects of the biology of plants growing in natural habitats or those cultivated in human-controlled environments. In other words, the vast majority of the studies pay attention to PRD not as a development process within agriculture or an institution that is dedicated to a sustained production of food and other non-food materials.

There is therefore a need to examine Plant Resource Domestication (PRD) in relation to the development of agriculture. The outcomes of such an examination are likely to facilitate the conception of development models that are built on the foundations that are inherent to agriculture. For this reason, the study explores the practice of PRD with the overall aim of understanding its nature in relation to the development of agriculture. But to achieve the overall aim, the following were of strategic importance: (i) the fundamental processes that characterise the transition of cultivated plants from their wild to the cultured state (ii) the 
syndrome that defines the development of crops irrespective of place and period in history (iii) an interpretation of Plant resource Domestication (PRD) in terms of the development levels in plants and their significance to agriculture.

\section{Understanding Plant Resource Domestication (PRD)}

Vegetative life forms may be distinguished based on their habitat, morphology and life cycle. They are either aquatic or terrestrial plants with regards to habitat; herbs, shrubs or trees based on their morphology; annuals, biennials or perennials according to their life cycle. Some of these varied forms of vegetative species are endemic to certain regions or continents. Wild species of olives, pecan and rubber have been reported to be native to the Mediterranean region, North America and South America respectively [9]. Similarly, several species of groundnut, potato, and tomato are known to be natural-occurring plants in South America [31-33]

From the vast number of plant species across the continents are those which have been identified to be valuable for either dietary or non-dietary purposes. Parts of plants are now common sources of food, vegetable oils, fibre, latex and other products for both individuals and industries [34]. Nevertheless, the utilization of crop wild relatives in the genetic improvement of crops is becoming more prominent in different regions of the world [13]. The significance of plants for food and agriculture is now a criterion for defining plants as a resource by technical commissions such as the International Treaty on Plant Genetic Resource for Food and Agriculture (ITPGRFA). However, the challenges resulting from anthropogenic influences on natural ecosystems makes it an imperative to preserve natural plant population, maintain conditions for genetic evolution and reduce the rate of plant genetic erosion [35,36]. These conservation goals are usually achieved through the in-situ and ex-situ methods. The Sierra de Manantian Reserve in Mexico established for the conservation of perennial wild relatives of maize and the Erebuni Reserve created to conserve wild relatives of cereals are major in-situ conservation projects [37]. Similarly, the Royal Botanical Gardens-Kew with its different sections such as botanical gardens, field gene banks and seed gene banks including the Millennium Seed Bank Project is recognised by ITPGRFA as a major ex-situ conservation project.

Domestication of useful plants from natural populations may have been driven primarily by the desire to sustain the production of their products. It is not uncommon to categorised the process of plant domestication into an initial, intermediate and final phase [2-4]. The initial phase of plant domestication involves the production of plant products through the protection of valued plants, small-scale clearance of vegetation and minimal tillage. These preliminary activities progress into the second phase of domestication, or better still, the cultivation of selected native plants which involves clearance at a larger scale and systematic tillage in human-controlled environments. Similarly, the exercises at the intermediate phase usher in the final phase of domestication otherwise described as the cultivation of tamed plants in fields or other agricultural ecosystems. Interestingly, the different phases of PRD are characterised by fundamental changes to the bio-physical environment (ecological aspect) and the genetic advancements in plants (genetic aspect) [38].

\subsection{The Ecological Aspect of PRD}

The initial phase of PRD remains blurred given the fact that it occurred several hundreds of years ago during the early period of the Neolithic revolution. Nevertheless, it is most certain that resources of plant origin were exploited for various purposes and preserved within natural habitat prior to their transfer to artificial environments [2-4]. Grains of wild rice growing in the swampy basin of the upper Niger river and the Asian plains are reported to have been gathered by humans before their cultivation in fields [39]. Likewise, pods of the wild peanuts were collected by the ancients from their natural habitat prior to their cultivation on farmlands [21]. Natural population of avocado trees were restructured into forest gardens while their seedlings were later transferred to artificial ecosystems by the earliest inhabitants of Mesoamerica [4,5]. More recently, blueberries and cranberries were relocated to agricultural ecosystems after a long period of exploitation across North America [5].

In some cases, seeds or seedlings of plants were transported from their native range to other continents as witnessed during the period of European global exploration. Recently domesticated plants which are only few generations away from their wild ancestors, provide insights into the early phase of plant domestication. The domestication of rubber serves as a typical example. Collection of rubber seeds and their transfer to a botanical garden in England changed the status of the plant as one that is restricted to the Amazonian forest [40]. The young seedlings that developed from the few germinated seeds were later transported to southeast (SE) Asia. As a result, the rubber plant now grows extensively in plantations across SE Asia and other parts of the world through the use of generations of those young trees that were supplied from England as planting materials [40]. A similar fate characterized the Kiwi vine which grows naturally in the western region of China before its transfer to human-controlled environments in New Zealand [28]. Today, the presence of kiwi plantations in Europe, Latin America and North America could be traced to its developments in artificial environments in New Zealand. Similarly, the development of the macadamia into a commercial crop began with a transfer from its native range in Australia to humancontrolled environments in Hawai'i [29]. All cultivated plants, like the rubber and kiwi vine, were growing in natural habitats in restricted areas or regions prior to their transfer into agricultural ecosystems.

\subsection{The Genetic Aspect of PRD}

Wild plants are continuously being transformed due to changes in their genetic materials. The genomic structure of 
plants have been altered either through the aid of natural mechanisms or by human-induced selection and hybridization $[11,15,16,18,26,30]$. Simple genetic materials in wild plants evolved into relatively complex forms by a process sometimes referred to as polyploidization or Genome-Wide Duplication (GWD). The evolution of simple plants into their advanced form through the process of GWD has been demonstrated in a number of seed and fruit-bearing plants [15-17]. More recently, the relationships between the genetic structures of wild species of peanuts (Arachis) and their cultivated form as well as those of apple (Malus) and their domesticated equivalent have been deciphered. Two diploid wild species of peanut Arachis duranensis and Arachis ipanensis and one allotetraploid A. monticola are among the several species of wild peanuts [21,32]. The fusion of the A-genome of $A$. duranensis and B-genome of $\mathrm{A}$. ipanensis, after cross-pollination and during fertilization, resulted in different allotetraploid populations having two chromosomes sets with differences in centromeric band [21]. The only known extant allotetraploid $A$. Monticola under the pressure of selection in agro-ecological conditions may have been transformed into cultivated groundnut (Arachis hypogaea). In ways similar to the development of cultivated peanut, simple chromosomes in the wild apple (Malus. sieversii) underwent series of duplication that lead to the formation of the complex gene pool in cultivated apple (Malus domestica) [22]. A similar duplication characterise the genomic relationship between wild grape (Vitis sylvestris) and its cultivated form (Vitis vinifera) [23].

A more efficient means of accelerating the transformation of wild plants has been through human-induced changes to plant genome. Direct human interventions in the form of breeding programmes often produce varieties of plants with superior traits. The outcomes of breeding programmes involving rice and oil palm demonstrate the significance of genetic improvement in the process of domestication. Some species of wild rice contain beneficial genes such as those with resistance to rice grassy stunt virus (RGSV) which are absent in cultivated rice Oryza sativa [11,30]. Breeding programmes involving wild species and varieties of cultivated rice $(O$. sativa) produce viable progeny that were further backcrossed with varieties of cultivated rice. The systematic breeding which involves three backcrosses succeed in transferring the gene for grassy stunt resistance and other beneficial traits into cultivated rice [11,30]. Such breeding programmes have been adopted by several institutions including the International Rice Research Institute for the development of cultivated rice varieties that are resistant to RGSV. In like manner, breeding programmes have also significantly improved the transformation of the oil palm. Natural populations of the thick-shelled deli dura fruit type and the shell-less pisifera type are homozygous for shell thickness. A monohybrid cross between both populations resulted in thin-shelled tenera that is heterozygous for the trait of shell thickness. The changes in the genetic structure of the hybrid tenera fruit type allow the formation a thin shell which in turn facilitated increases in mesocarp size and oil yield [26].

Genetic improvement is therefore critical in the process of adapting plants to agro-ecological conditions. The genetic structure of allotetraploid cultivated peanut which is the sum of two genomes is an improvement over genome-A and genome-B of $A$. duranensis and A. ipanensis respectively. In this regard, the complex genome of cultivated apple may be said to be genetically superior to the simple genetic materials of its wild relatives. The superior genetic structure of cultivated rice varieties with RGSV resistant gene confers on the rice plant a greater adaptability to agro-ecological conditions just as the heterozygous genes for shell thickness in thin-shelled tenera fruit type is genetically an advantage over the homozygous ones in thick-shelled deli dura fruit type. Accordingly, the advances in the genetic structure of plants under selection and during domestication induce series of desired traits such as compact growth habit, larger fruits size, higher productivity and non-shattering of seeds [6$8,19,24,26]$.

\section{PRD: The Pathway to the Development of Crops}

A number of plants have been transformed into crops through the domestication event. They include some native vegetative species such as rice, peanut, potato including few vines and trees (see Table 1). Other native plants would be transformed into crops in the future through the same platform of domestication [9]. Nevertheless, wild plants are continuously being subjected to the selective pressures within the domestication process whenever they are found to be beneficial to humans. Recently, some wild plants or partiallydeveloped plants in Africa and South America have also experienced the transforming-effect of domestication. One of such plant is the quinoa; whose transition from the intermediate phase of domestication to the final state is only just been achieved [27]. From among the others are the African oil palm and African bush mango. The development of the oil palm into a crop of global importance is less than a century $[10,41]$ while the African bush mango is presently responding to human-induced selection in artificial environments $[42,43]$.

The quinoa is of the plant family Chenopodiaceae, genus Chenopodium and scientifically referred to as Chenopodium quinoa. Grains of this plant are highly valued by the indigenous people of South America as indicated by the FAO technical report "Quinoa, an ancient crop to contribute to world food security". The food value of quinoa may have necessitated its domestication by the indigenous people. However, the process of domesticating the plant suffered a setback due to the introduction of foreign crops as well as the presence in its grains of a bitter substance saponin. The most recent discovery that quinoa grains contain high levels of essential amino acids and vitamins renewed interest in its domestication. Breeding programme involving quinoa grown on experimental fields in Europe produced true hybrids with 
distinct traits such as reduced height at maturity, early flowering, early maturity and higher yield [27]. More still, selection of the best performing genotypes in the course of the breeding programme resulted in the development of three new varieties that are insensitive to length of days and are saponin-free. The development of hybrid quinoa which somehow coincides with the "International Year of the Quinoa" declared by FAO remains the most likely planting materials in future Quinao Projects.

The oil palm, unlike the quinoa, has gained international recognition as a crop of global importance. It is of the plant family Palmae, genus Elaeis and scientifically referred to as Elaeis guineensis [41]. Oil palm trees which grow only in the African rainforest were preserved on farmlands hundreds of years leading to the formation of semi-wild grooves $[3,4,41]$. Its domestication in modern history began with the transfer of seedlings out of its native continent. In 1848, some oil palm seedlings were transported from its native range to Southeast (SE) Asia where they were planted in the Botanic Garden of Bogor, Indonesia [41]. The young oil palm seedlings grew rapidly in their new habitats characterised by relatively higher rainfall and longer photoperiods as well as express higher productivity due to the partitioning of more resources for the production of fruit bunch [44,45]. This productivity-enhancing effect of SE Asia climatic conditions on oil palm is further enhanced by the absence of major pest and diseases which are common environmental challenges in West Africa. These factors-faster growth rate and higher productivity- contribute to the establishment of commercial plantations of oil palm from generations of those oil palm seedlings earlier transported from West Africa. In plantation, selection of oil palms for yield produced progenies with higher productivity. Generations of plantation-grown oil palms manifest productivity levels that exceed those of their parents by more than 50 percent $[10,41]$. More still, "hybrids" of oil palms obtained from plant breeding programme has further increased the production levels making them the preferred planting materials in the development of major oil palm projects $[26,41]$. As a result, plantation-grown oil palm now satisfies global demand for palm oil while simultaneously replacing semi-wild palm grooves as the major source of the product. The oil palm which was once restricted to regions of Africa is now a crop of global importance as a result of the domestication event.

Attempts at transforming the African bush mango into a crop trail the success story of oil palm domestication. The African bush mango which grows naturally as two known species in the humid lowland forest of Africa [46] bears edible fruits which are valued by the indigenous peoples of West and Central Africa. The two known species Irvingia gabonensis and Irvingia wombolu are often preserved on farmland during land preparation due to their value as food source. As a result, protected bush mango trees progressively flourish in the course of successive farming season as their growth proceeds without restriction from Competitors. The progress of preserved trees on farmland is perhaps the stimulus behind the transplantation of wild seedlings onto farmlands. Yet, the expectation of famers that the cultivation of bush mango on farmland becomes a reality just as other crops lead to the adoption of bush mango domestication programmes [47-49]. The domestication programmes facilitates the collection of bush mango from its centre of diversity and its propagation in nurseries using vegetative propagation methods [50,51]. Through these efforts, the maturation period of bush mango reduced from well over a decade in their natural habitats to about 5 years in humancontrolled environments $[42,43]$. Furthermore, the selection of high yielding trees is on-going since there are indications that genotypes with superior production traits exit within the population of field-grown bush mango.

Table 1. Selected wild plants and their domesticates as crops

\begin{tabular}{|c|c|c|c|c|}
\hline $\begin{array}{l}\text { WILD } \\
\text { PLANTS }\end{array}$ & GENUS & $\begin{array}{l}\text { ESTIMATES OF SPECIES \& } \\
\text { SOME NOTABLE SPECIES }\end{array}$ & $\begin{array}{l}\text { PROGENITOR OF } \\
\text { DOMESTICATE }\end{array}$ & $\begin{array}{l}\text { CUTIVATED } \\
\text { SPECIES }\end{array}$ \\
\hline RICE* & Oryza & $\begin{array}{l}21 \text { species } \\
\text { O. breviligulata } \\
\text { O. nivara } \\
\text { O. rufipogon } \\
68 \text { Species }\end{array}$ & $\begin{array}{l}2 \text { species } \\
\text { O. breviligulata } \\
\text { O. nivara }\end{array}$ & $\begin{array}{l}2 \text { species } \\
\text { O. glaberrima } \\
\text { O. sativa }\end{array}$ \\
\hline PEANUT* & Arachis & $\begin{array}{l}\text { A duranensis } \\
\text { A. monticola }\end{array}$ & A. monticola & A. hypogaea \\
\hline POTATO* & Solanum & $\begin{array}{l}206-232 \text { species } \\
\text { S. brevicaule }\end{array}$ & $\begin{array}{l}\text { Several species collective referred } \\
\text { to as Solanum brevicaule complex. }\end{array}$ & $\begin{array}{l}7 \text { species; } 1 \text { is of global } \\
\text { importance. } \\
\text { S. tuberosum }\end{array}$ \\
\hline GRAPE* & Vitis & $\begin{array}{l}\text { Over } 200 \text { species } \\
\text { Vitis sylvestris }\end{array}$ & Vitis sylvestris & $\begin{array}{l}\text { Few species grown as } \\
\text { root stock on which } \\
\text { Vitis vinifera is grafted. }\end{array}$ \\
\hline APPLE* & Malus & $\begin{array}{l}27 \text { species } \\
\text { M. sieversii } \\
\text { M. sylvestris }\end{array}$ & M. sieversii & M. domestica \\
\hline RUBBER* & Hevea & $\begin{array}{l}9 \text { species } \\
\text { H.brasiliensis }\end{array}$ & H.brasiliensis & H.brasiliensis \\
\hline
\end{tabular}

*indicates source(s).

Rice*: [11],[30],[39]; Peanut*: [21];[32]; Potato*: [20],[31]

Grape*: [23],[56]; Apple*: [22],[54]; Rubber*:[40],[55] 


\section{Significance of PRD in the Development of Agriculture}

The significance of domesticating plants of wild origin is made evident in the development of crops or plants that are adapted to artificial environments.

Domestication modifies the growth habit in vegetative species and regularises their flowering-fruiting pattern. The growth pattern of wild plants which is subject to the influence of wide range of environmental factors often manifests prolonged growth period as indicated by its extended juvenile phase and late maturation[52,53]. However, series of selection and genetic improvement activities have modified the growth habit and reduced the maturation period. For instance, series of selection as well as successive breeding modified the perennial, highly branched wild relative of maize (teosinte) to an annual plant with a compact growth habit $[6,19]$. More recently, the transfer of bush mango to human-controlled environment have reduced its maturation age from well over a decade to about 5 years $[42,43]$. Likewise, nursery-grown seedlings of macadamia plant that were transferred to fields commence flowering and fruiting about 15years earlier when compared to some of its wild counterparts [29]. Furthermore, advances in selection techniques have gradually altered the flower-fruiting pattern of macadamia trees from its known irregular pattern to a fairly consistent one. Similarly, selection of desired traits in quinoa has also modified growth pattern and accelerated the attainment of maturity [22]. Domestication, through the modification of growth and flowering-fruiting pattern regularization, increases the productivity of vegetative species. In nature, the productive capacities of vegetative species are not fully expressed due to interferences from environmental factors [53]. Nevertheless, productivity increases when these restrictions are surmounted through series of selection that allows the partitioning of more dry matter for generative growth $[44,45]$. The productivity of modern clones of rubber is over seven times higher than those of wild rubber trees due to the domestication event [40]. A similar increase in productivity as a result of advances in selection and plant breeding techniques characterise the domestication of oil palm $[10,41]$. Again, fruit size of tomato gradually increased from small to large under selection and during domestication $[12,24]$. The interesting aspect of the increase in the size of tomato fruit relates to the expression pattern of certain genes. The expression patterns of both the small-fruited and large-fruited alleles at the early stages of fruit development in wild tomato produce small fruits. But an alteration to the expression pattern of the large-fruited alleles to later stages of fruit development in cultivated tomatoes allows for the development of fruits into larger forms [12,24] In a similar way, fruits of cultivated apple (Malus domestica) are significantly larger than those of its wild relative (Malus spp) due largely to differences in the expression of certain genes [14,22].

From the fore-going discussion, the domestication of plants is at the same time a transformation in their state, form and function. Generally, the different vegetative species that are confined to natural habitats are usually free from the effects of human influence. For instance, the perennial Oryza rufipogon, its annual derivative $O$. nivara and all the other natural-occuring species of rice (see Table 1) are in a primitive state. Similarly, the diploid Arachis duranensis, the allotetraploid A. monticola and all the other species of peanut (See Table 1) are in a wild state. In the same way, the wild apple Malus sieversii, M. sylvestris and other native species (Table 1) are in a simple state. All these vegetative species in the wild-primitive-simple state may simply be referred to as plants. In the wild-primitive-simple state, plants exhibit highly branched growth habit (their form) and are important only as an integral part of an ecosystem (their function). From a development perspective, all plants including the natural-occurring species of potato, grapes and rubber (Table1) with untamed form and "ecosystem-based" function are in the Primary Level of Plant Development, that is, a level where plant-human interaction is either minimal or completely absent.

Some plants attract attention in the course of interaction between humans and vegetative species. Such plants are subjected to a number of evaluations to determine their value in terms of nutrition and other purposes. Only very few species of plants are confirmed to be of value after evaluation exercises as shown in Table 1. The allotetraploid $A$. monticola in comparison to the over 60 species of peanut plant is found to be the most valuable after evaluations by the ancients [21]; the Solanum brevicaule complex from the vast array of potato species wins human appreciation [20]; just as Vitis sylvestris is among the few species of grapes which constitutes the focus of human attention [23]. Preferences for plants based on the outcomes of previous evaluations facilitate their continuous exploitation for either food or nonfood purpose. With the onset of exploitation, a plant is valued not just as a mere vegetative species but a plant resource, that is, a "utility plant" or a plant of direct value to humans. At the stage of exploitation, the function of a plant resource is partially enhanced even though it still retains a highly branched growth habit (its form). The function of a plant resource now transcends the "ecosystem-based" dimension of its primitive state to include a "utility-based" aspect but still remains outside the control of humans. Accordingly, such exploitable plants have evolved from the primitive state or Primary Level of Plant Development to an intermediate state or Secondary Level of Plant Development. Better still, the Secondary Level of Plant Development is that level at which human-plant interaction is based on purpose.

Plant resource undergoes further development through relocation from its natural habitat to human-controlled environment. They experience characteristic changes to their external morphology and genetic materials under the influence of selective pressures inherent in the domestication 
process. Interestingly, cultivated plants under steady influence of selection are progressively transformed into crops. Again Table 1 indicates plant resource as progenitors of crops. The transfer to human-controlled conditions and continuous cultivation of $O$. breviligulata and $O$. nivara lead to the development of species of cultivated rice $O$. glaberrima and $O$. sativa respectively; Arachis monticola produced A. hypogaea the cultivated peanut and from the Solanum brevicaule complex emerged $S$. tuberosum the cultivated potato[8,20,21,39]. Similarly, selection activities concerning Vitis sylvestris , M. sieversii , and H.brasiliensis in agricultural ecosystems lead to the emergence of commercial grape $V$. vinifera, cultivated apple $M$. domestica and domesticated rubber H.brasiliensis respectively $[22,23,40]$. At this stage where a plant resource transit into a crop; the alteration to their form and function becomes definitive. The highly branched growth habit of plants (their form) is transformed into a compact form while their "utilitybased" function is outstretched towards a sustainable level since the plant is now under the partial or total control of humans. Accordingly, the transformation of plant resource into a crop is simultaneously a transition from an intermediate state or Secondary Level of Plant Development to the advanced state or Tertiary Level of Plant Development. In other words, Tertiary Level of Plant Development is that level at which the form of a plant is completely modified and its function substantially enhanced due to human dominance over the plant.

Development of plants at an advanced level usually reorients the functions of the lower levels towards a novel purpose. The novelty conferred on less developed plants results from advances in breeding technologies including those related to introgression of beneficial genes from wild plants into crops. For instance, the development of cultivated rice facilitated the demise of $O$. breviligulata and $O$. nivara as plant resource with a food value. Yet, the relatively recent use of these wild progenitors in systematic breeding programmes to genetically improve cultivated rice produced novel cultivars that are resistant to certain pathogens $[11,30]$. Furthermore, breeding programmes have also elevated other wild species without known food value to plant resource due to their contributions to genetic improvement of crops. Put differently, operations at the Tertiary Level of Plant Development have redirected the function of wild progenitors of rice from "plant resource that were valued for food" to that of "plant resource that are valued for breeding purpose". On the other hand, it has conferred "utility-based" function on distant relatives of rice which hitherto had only "ecosystem-based" function. This trend in the human-plant relationship for rice also characterise those of other plants such as potato, grape and apple.

\section{Conclusion}

The study whose sole aim is to understand agriculture from a development perspective using the instrument of Plant Resource Domestication may be structured into two parts.
The first part reviews (i) the activities which are critical for a successful transition of vegetative species from wild to the cultured state (ii) the "syndrome" or impact of domestication on plants in different regions since prehistoric times to the present age. The second part interprets the different phases in PRD including the advances in the form and function of plants in terms of developments in agriculture. Agriculture when viewed from a development perspective to Plant Resource Domestication (PRD) may be expressed as follows:

- Agriculture involves human-plant interactions through which the genetic potentials of plants are rationally explored and utilized thereby highlighting the ingenuity of man.

- Agriculture is a system of development which consists of a number of crop-based development organs that are formed through the development process PRD.

- The development process and the development organs suggest the existence of a development architecture within agriculture.

\section{References}

[1] D. Zohary and P. Spiegel-Roy, "Beginning of fruit growing in the Old World". Science Vol. 187, pp. 319-32. 1975.

[2] D.R. Harris, "An evolutionary continuum of people-plant interaction", in Foraging and farming, the evolution of plant exploitation. D.R. Harris and G.C. Hillman Eds. Unwin Hyman, London. 1989. Pp. 11-26.

[3] K.F. Wiersum, "Domestication of valuable tree species in agro-forestry systems: evolutionary stages from gathering to breeding", in Domestication and commercialization of nontimber forest products for Agroforestry . FAO Tech Paper No. 9 FAO, Rome. pp. 147-158. 1996.

[4] K.F. Wiersum, "From natural forests to tree crops, codomestication of forests and tree species, an overview". Netherlands J Agric Sci. Vol. 45, pp. 425-438. 1997.

[5] J. Janick, "The origin of fruits, fruit growing and fruit breeding". Plant Breeding Reviews Vol. 25, pp. 255-320. 2005.

[6] J. Doebley and A. Stec, "Inheritance of the morphological differences between maize and teosinte: comparison of results for two F2 populations". Genetics 134: 559-570. 1993.

[7] E.M.K. Koinange, S.P. Singh and P. Gepts, "Genetic control of the domestication syndrome in common bean". Crop Science Vol. 36, pp. 1037-1045. 1996.

[8] C. Li, A. Zhou and T. Sang, "Genetic analysis of rice domestication syndrome with the wild annual species, Oryza nivara”. New Phytologist Vol.170, pp. 185-194. 2006.

[9] B.E. Uchola, "A development perspective to Tree Resource Domestication in Agriculture". Int J Agric and Forestry Vol. 4(6), 459-464. 2014.

[10] A.C. Zeven, "The partial and complete domestication of oil palm (Elaeis guineensis)". Economic Botany Vol. 26, pp. 274279. 1972. 
[11] D.S. Brar, R. Dalmacio, R. Elloran, R. Aggarwal, R. Angeles and G.S. Khush, "Gene transfer and molecular characterization of introgression from wild Oryza species into rice", in Rice Genetics Ill, International Rice Research Institute, Manila-Philippines. 477-486. 1996.

[12] T.C. Nesbitt and S.D. Tanksley, "Comparative sequencing in the genus Lycopersicon: Implications for the evolution of fruit size in the domestication of cultivated tomatoes". Genetics Vol. 162, pp. 365-379. 2002.

[13] R. Hajjar and T. Hodgkin, "The use of wild relatives in crop improvement: a survey of developments over the last 20 years". Euphytica Vol. 156, pp. 1-13. 2007.

[14] B.J. Janssen, K. Thodey , R.J. Schaffer, R. Alba, L. Balakrishnan, R. Bishop, J.H. Bowen, R.N. Crowhurst, A.P. Gleave, S. Ledger, S. Mcartney, F.B. Pichler, K.C. Snowden and S. Ward, "Global gene expression analysis of apple fruit development from the floral bud to ripe fruit". BioMed Central (BMC) Plant Biology 8:16. 2008.

[15] J.O. Osuji, G. Harrison, J. Crouch and J.S. Heslop-Harrison, "Identification of the genomic constitution of Musa L. lines (bananas, plantains and hybrids) using molecular cytogenetics". Annals Botany Vol. 80, pp. 787-793. 1997.

[16] M.W. Chase, S. Knapp, A.V. Cox , J.J. Clarkson, Y. Butsko, J. Joseph, V. Savolainen and A.S. Parokonny, "Molecular systematics, GISH and the origin of hybrid taxa in Nicotiana (Solanaceae)". Annals Botany Vol. 92, pp. 107-127. 2003.

[17] X.H. Li, K.J. Wang and J.Z. Jia, "Genetic diversity and differentiation of Chinese wild soybean germplasm (G. soja Sieb. \& Zucc.) in geographical scale revealed by SSR markers". Plant Breeding Vol. 128(6), pp. 658-664. 2009.

[18] X. Huang et al., "A map of rice genome variation reveals the origin of cultivated rice". Nature 490: 497-501. 2012.

[19] J. Doebley and A. Stec, "Genetic analysis of the morphological differences between maize and teosinte". Genetics Vol. 129, pp. 285-295. 1991.

[20] D.M. Spooner, K. Mclean, G. Ramsa, R. Waugh and G.J. Bryan, "A single domestication for potato based on multilocus amplified fragment length polymorphism genotyping". Proceedings of the National Academy of Sciences of the United States of America (PNAS) Vol. 102, pp. 14694-14699, 2005.

[21] G. Seijo, G.I. Lavia, A. Fernandez , A. Krapovickas, D.A. Ducasse, D.J. Bertioli and E.A. Moscone, "Genomic relationships between the cultivated peanut (Arachis hypogaea, Leguminosae) and its close relatives revealed by Double Gish”. Amer. J. Bot. Vol. 94(12), pp. 1963-1971, 2007.

[22] R. Velasco et al., "The genome of the domesticated apple (Malus domestica Borkh)". Nature Genetics Vol. 42, pp. 833839,2010

[23] S. Myles, A.R. Boyko, C.L. Owens, P.J. Brown, F. Grassi, M.K. Aradhya, B. Prins, A. Reynolds, J.M. Chia, D. Ware, C.D. Bustamante and E.S. Buckler "Genetic structure and domestication history of the grape". Proceedings of the National Academy of Sciences of the United States of America (PNAS) Vol. 108, pp. 3530-3535, 2011.

[24] B. Cong , J. Liu and S.D. Tanksley, "Natural alleles at a tomato fruit size quantitative trait locus differ by heterochronic regulatory mutations". Proceedings of the National Academy of Sciences of the United States of
America (PNAS) Vol. 99, pp. 13606-13611, 2002.

[25] D. Sparks, "Pecan" in Handbook of Fruit Set and Development, S. P. Monselise Ed., Boca Raton, Florida: CRC Press. 1986. Pp. 323-339.

[26] J.J. Hardon, R.H.V. Corley and C.H. Lee, "Breeding and selecting the oil palm", in Improving vegetatively propagated crops. A.J. Abott and R.K. Atkin Eds, Academic Press, London. 1987. Pp. 63-68.

[27] H.D. Mastebroek, E.N. Van Loo and O. Dolstra, "Combining ability for seed yield traits of Chenopodium quinoa breeding lines”. Euphytica Vol. 125(3), pp. 427-432, 2002.

[28] H.W. Huang and A.R. Ferguson, "Genetic resources of kiwifruit domestication and breeding". Horticultural Reviews Vol. 33, pp. 1-121, 2007.

[29] C.M. Hardner, C. Peace, A.J. Lowe, J. Neal, P. Pisanu, M. Powell, A. Schmidt, C. Spain and K. Williams, "Genetic Resource and Domestication of Macadamia". Horticultural Reviews Vol. 35, pp. 1-125, 2009.

[30] D.S. Brar and G.S. Khush, "Alien introgression in rice". Plant Molecular Biology Vol. 35, pp. 35-47, 1997.

[31] R.J. Hijmans and D.M. Spooner, "Geographic distribution of wild potato species”. Amer. J Bot. Vol. 88(11), pp. 2101-2112, 2001.

[32] A. Jarvis et al., "Biogeography of wild Arachis: assessing conservation status and setting future priorities". Crop science Vol. 43(3), pp. 1100-1108, 2003.

[33] R.T. Chetelat, R.A. Pertuze, L. Fau'ndez, E.B. Graham and C.M Jones "Distribution, ecology and reproductive biology of wild tomatoes and related nightshades from the Atacama Desert region of northern Chile". Euphytica Vol.167, pp. 77-93, 2009.

[34] E. Marshall and C. Chandrasekharan, Non-farm income from non-wood forest products. FAO Diversification booklet number 12. 2001.

[35] G. Namkoong, "Forest genetics: pattern and complexity". Canadian J Forest Research Vol. 31(4), pp. 623-632. 2001.

[36] S. Stolton, N. Maxted, B. Ford - Lloyd, S.P. Kell and N. Dudley, Food Stores: using protected areas to secure crop genetic diversity. WWF Arguments for protection series. WWF, Gland, Switzerland. 2006.

[37] N. Maxted and S.P. Kell, Establishment of a global network for the in situ conservation of crop wild relatives: status and needs. FAO Commission on Genetic Resources for FAO, Rome, Italy. 2009.

[38] J.R. Harlan, "Origin and processes of domestication", in Grass Evolution and Domestication, G.P.Chapman Eds. Cambridge, UK: Cambridge University Press. 1992. Pp. 159-175.

[39] G.S. Khush, "Origin, dispersal, cultivation and variation of rice”. Plant Molecular Biology Vol. 35, pp. 25-34, 1997.

[40] R.E. Schultes, "The domestication of the rubber tree: economic and sociological implications". Amer J Econ Soc Vol. 52 (4), pp. 479-485. 1993.

[41] C.D. Ataga and H.A.M. Van Der Vossen "Elaeis guineensis Jacq". In: Van Der Vossen, HAM \& Mkamilo GS (eds). PROTA 14: Vegetable oils/Oléagineux. [CD-Rom]. Wageningen, Netherlands. 2007. 
[42] D.O. Ladipo, J.M. Fondoun and N. Ganga, "Domestication of the bush mango (Irvingia spp.): some exploitable intraspecific variations in west and central Africa", in Domestication and commercialization of non-timber tree products for Agro-forestry. FAO Tech Paper, No. 9. FAO, Rome. 1996. Pp. 193-205.

[43] A.R. Atangana, Z. Tchoundjeu, J-M. Fondoun, E. Asaah, M. Ndoumbe and R.R.B. Leakey, "Domestication of Irvingia gabonensis: I. Phenotypic variation in fruit and kernel traits in two populations from the humid lowlands of Cameroon". Agroforestry Systems. Vol. 53, pp. 55-64, 2001.

[44] R.H.V. Corley, B.S. Gary and S.K. Ng, "Productivity of the oil palm (Elaeis guineensis Jacq.) in Malaysia". Experimental Agriculture Vol. 7, pp. 129-136, 1971a.

[45] R.H.V. Corley, J.J. Hardon and G.Y. Tan, “Analysis of growth of the oil palm (Elaeis guineesis Jacq) I. Estimation of growth parameters and applicaton in breeding". Euphytica Vol. 20, pp. 304-315. 1971b.

[46] D.J. Harris, "A revision of the Irvingiaceae in Africa". Bulletin du Jardin Botanique National de Belgique, Vol. 65, pp. 143196. 1996.

[47] R.R.B. Leakey and A.J. Simons, "The domestication and commercialization of indigenous trees in agroforestry for the alleviation of poverty". Agroforestry Systems Vol. 38, pp. 165-176, 1998.

[48] Z. Tchoundjeu, B. Duguma, J-M. Fondoun and J. Kengue, "Strategy for the domestication of indigenous fruit trees of West Africa: case of Irvingia gabonensis in southern Cameroon". Cameroon J Biol Biochem Sci Vol. 4, pp. 21-28, 1998.

[49] E.T. Ayuk, B. Duguma, S. Franzel, J. Kengue, M. Mollet, T. Tiki-Manga and P. Zenkeng "Uses, management and economic potential of Irvingia gabonensis in the humid lowlands of Cameroon". Forest Ecol Mgt, Vol. 113, pp. 1-9. 1999.
[50] R.R.B. Leakey, J.F. Meseân, Z. Tchoundjeu, K.A. Longman, J.McP. Dick, A.C. Newton, A. Matin, J. Grace, R.C. Munro and P.N. Muthoka, "Low-technology techniques for the vegetative propagation of tropical trees". Commonwealth For Rev Vol. 69, pp. 247-257. 1990.

[51] P.N. Shiembo, A.C. Newton and R.R.B. Leakey, "Vegetative propagation of Irvingia gabonensis, a West African fruit tree". Forest Ecol Mgt Vol. 87, pp. 185-192. 1996.

[52] E.E. Goldschmidt and S.P. Monselise, "Physiological assumptions toward the development of a Citrus fruiting model", in Proceedings of the International Society of Citriculture, W. Grierson. Ed., Lake Alfred, Florida. 2:668 672. 1977.

[53] S.P. Monselise and E.E. Goldschmidt, "Alternate bearing in fruit trees": A review. Horticultural Reviews Vol. 4, pp. 128 173. 1982.

[54] P.L. Forsline, H.S. Aldwinckle, E.E. Dickson, J.J. Luby and S.C. Hokanson, "Collection, maintenance, characterization, and utilization of wild apples of Central Asia". Horticultural Review, Vol. 29, pp. 1-61, 2003.

[55] R.E. Schultes, "A brief taxonomic view of the genus Hevea. Malaysian Rubber" Research and Development Board, Kuala Lumpur. Monograph no. 14, 1990.

[56] USDA- ARS. 2014. Germplasm Resources Information Network, in http://www.ars-grin.gov/cgibin/npgs/html/splist.pl?12735 (29 December 2014) 